\title{
Design, synthesis, and evaluation of antitubercular activity of a novel benzothiazole-containing an azetidinone ring
}

\author{
Sibaji Sarkar* \\ Department of Pharmaceutical Chemistry, Noble Pharmacy College, Near Bamangam, Via-Vadal, Junagadh, India
}

Cite this article as: Sarkar S. Design, Synthesis, and Evaluation of Antitubercular Activity of Novel Benzothiazole-Containing an Azetidinone Ring. Istanbul; Istanbul J Pharm 48 (2): 28-31.

\begin{abstract}
Recent studies have demonstrated that 2-amino-substituted benzothiazole derivatives exhibit significant antitubercular activity. In this study, new compounds of benzothiazole-containing azetidinone derivatives were designed and synthesized using substituted benzaldehydeN-(5fluoro-1,3-benzothiazol-2-yl) semicarbazone, chloroacetyl chloride, and triethylamine in DMF. The structures of the synthesized compounds were characterized by TLC, IR, elemental analysis, and $1 \mathrm{H}$ NMR. In vitro screening data revealed that all the designed and synthesized compounds A6-A10 exhibited the ability to inhibit the growth of Mycobacterium tuberculosis in terms of MIC. Variable and modest activity was observed against the investigated strains of bacteria; however, the compound A6 exhibited significant antitubercular activity against M. tuberculosis H37Rv (MTCC 200) compared to that of the reference drugs isoniazid and rifampicin. These experimental data were consistent with our computational predictions in terms of the compound A6 that exhibited a satisfactory backbone for the antitubercular activity, perhaps due to an increase in hydrophobicity resulting in better penetration through the cell wall of $M$. tuberculosis.
\end{abstract}

Keywords: Benzothiazole, azetidinone, Mycobacterium tuberculosis, synthesis

\section{INTRODUCTION}

Benzothiazoles are an extremely important part of compounds that occur widely as biologically active natural products, as well as in the form of marketed drugs or drug candidates (Sarkar et al. 2008). Consequently, the development of an efficient and general methodology for synthesizing benzazoles is a meaningful research challenge with great potential for practical applications in the pharmaceutical industry. The feasible positions for the substitution group at the C-2 position exhibit various pharmacological properties such as antitubercular (Sarkar et al. 2013), antimicrobial (Sarkar et al.2011), anti-inflammatory (Sarkar et al. 2013), anthelmintic (Sarkar et al. 2008) and anticancer activities (Sarkar 2017). The 2-azetidinone ring system is a common structural feature of numerous wide-spectrum $\beta$-lactam antibiotics, including penicillins, cephalosporins, and carbapenems, which have been widely used as chemotherapeutic agents to treat bacterial infections and microbial diseases. The 2-azetidinones have been reported to possess a wide range of biological activities (Sarkar et al. 2008).

Based on the MDR and antitubercular activities of 2-substituted benzothiazoles, it appears that this backbone is an excellent lead compound for the development of novel antitubercular agents. It has been confirmed that there is an increase in hydrophobicity of the $\mathrm{OCH}_{3}$ group at the $\mathrm{C}-4$ position of the phenyl ring, which is attached to the azetidinone nucleus, which results in an increase in the antitubercular potency.

We had earlier confirmed that benzothiazoles with Schiff bases and azetidinone nucleus have diverse chemical reactivity and broad-spectrum biological properties such as antimicrobial and anthelmintic activities. 


\section{MATERIALS AND METHODS}

\section{Chemistry}

Laboratory chemicals were supplied by Chemdise Chemical Ltd (Rajkot, India). Melting points of the synthesized compounds were determined in open capillary and were uncorrected. IR spectra were recorded in Thermo Scientific; NICOLET iS10 spectrophotometer in $\mathrm{KBr}$ disc. ${ }^{1} \mathrm{H}$ NMR spectra were recorded on a 400-MHz spectrophotometer using DMSO- $\mathrm{d}_{6}$ as solvent and TMS as internal standard. The purity of the compounds was checked by TLC. Elemental analyses of all the compounds were in agreement with the calculated values. The antitubercular activity was evaluated at Micropharm Gandhinagar, Gujarat, India, using the Lowenstein-Jensen method.

The building block 2-amino-5-fluorobenzothiazole [2.023a-c] was prepared according to previously reported procedures (Sarkar et al. 2008).

General method for synthesizing ethyl (5-fluorobenzothiazol-2-yl) carbamate

2-Aminobenzothiazole (0.066 mole) $13.5 \mathrm{~g}$, absolute ethanol $30 \mathrm{~mL}$, anhydrous $\mathrm{K}_{2} \mathrm{CO}_{3}(2 \mathrm{~g})$, and ethyl chloroformate (0.0064 mole) $0.7 \mathrm{~g}$ were mixed at $0^{\circ} \mathrm{C}-5^{\circ} \mathrm{C}$. The mixture was heated for $7-8 \mathrm{~h}$ at $60^{\circ} \mathrm{C}-70^{\circ} \mathrm{C}$. The solution was filtered, and the solvent was evaporated under reduced pressure to obtain the product as a solid, which was recrystallized using ethanol.

General method for synthesizing N-(5-fluorobenzothiazol-2-yl)hydrazine carboxamide

Ethyl (5-fluorobenzothiazol-2-yl) carbamate (0.021 mole) 5.5 $\mathrm{g}$, treated with $4 \mathrm{~mL}$ of hydrazine hydrate, was dissolved in ethanol $(30 \mathrm{~mL})$. The reaction mixture was refluxed for $5 \mathrm{~h}$ and cooled to room temperature. The separated products were filtered, and the residue was washed with ethanol and recrystallized using ethanol.

General method for synthesizing substituted benzaldehyde $\mathrm{N}$-(5-fluorobenzothiazol-2-yl) semicarbazone

$\mathrm{N}$-(6-fluorobenzothiazol-2-yl)hydrazine carboxamide (0.02 mole) $5.21 \mathrm{~g}$ was dissolved in absolute ethanol, and substituted benzaldehyde (0.02 mole) $2.40 \mathrm{~g}$ was added and refluxed for $3 \mathrm{~h}$, and then the solvent was removed under reduced pressure to yield Schiff base.

\section{General method for synthesizing azetidinones from Schiff base}

To a solution of Schiff base $(0.10 \mathrm{~mol})$ in DMF, chloroacetyl chloride $(0.10 \mathrm{~mol})$ and triethyl amine $(0.10 \mathrm{~mol})$ were mixed and stirred for $24 \mathrm{~h}$. The reaction mixture was poured into cooled water and the liberated compound was extracted using chloroform. Evaporation of the compound afforded the corresponding azetidinones.

1-(3-chloro-2-oxo-4-(p-methoxyphenyl)azetidin-1-yl)-3-(5-fluorobenzothiazol-2-yl)urea (A6)

Yield 80\%; mp $175^{\circ} \mathrm{C}, \mathrm{IR}(\mathrm{KBr}) \vee \mathrm{cm}^{-1}: 3095(\mathrm{NH}), 1675(\mathrm{C}=\mathrm{O})$, $1605(C=N, C=C), 720(C-S), 680(C-C l),{ }^{1} H$ NMR $($ DMSO-d $) \delta$ (ppm):, 2.95 (s, 3H, OCH $), 3.95\left(\mathrm{~s}, 1 \mathrm{H}\right.$, azetidin $\left.\mathrm{C}_{4}-\mathrm{H}\right), 4.23(\mathrm{~s}, 1 \mathrm{H}$, azetidin $\left.\mathrm{C}_{3}-\mathrm{H}\right), 6.00\left(\mathrm{~s}, 1 \mathrm{H}, \mathrm{N}_{1}-\mathrm{H}\right), 7.68-$ ? $(\mathrm{m}, 7 \mathrm{H}, \mathrm{Ar}-\mathrm{H}), 8.45(\mathrm{~s}, 1 \mathrm{H}$, $\left.\mathrm{N}_{3}-\mathrm{H}\right)$. Anal. Calc. for $\mathrm{C}_{18} \mathrm{H}_{14} \mathrm{CIFN}_{4} \mathrm{O}_{3} \mathrm{~S}$ : $\mathrm{C}, 51.37 ; \mathrm{H}, 3.35 ; \mathrm{N}, 13.31$. Found: C, 51.35; H, 3.36; N, 13.29\%.

1-(3-chloro-2-oxo-4-phenylazetidin-1-yl)-3-(5-fluorobenzothiazol-2-yl)urea (A7)

Yield 77\%; 162 ${ }^{\circ} \mathrm{C} \mathrm{IR} \mathrm{(KBr)} \mathrm{\vee} \mathrm{cm}{ }^{-1}: 3010(\mathrm{NH}), 1680,1650(\mathrm{C}=\mathrm{O})$, $1601(\mathrm{C}=\mathrm{N}, \mathrm{C}=\mathrm{C}), 1152(\mathrm{C}-\mathrm{F}), 725(\mathrm{C}-\mathrm{S}),{ }^{1} \mathrm{H}$ NMR (DMSO-d $) \delta$ (ppm): $4.3\left(\mathrm{~s}, 3 \mathrm{H},-\mathrm{OCH}_{3}\right), 3.95(\mathrm{~s}, 1 \mathrm{H}, \mathrm{CH}-\mathrm{Cl}), 7.58-?(\mathrm{~m}, 8 \mathrm{H}, \mathrm{Ar}-\mathrm{H})$, $8.47(\mathrm{~s}, 1 \mathrm{H}, \mathrm{CONH}), 11.75(\mathrm{~s}, 1 \mathrm{H}, \mathrm{NH})$. Anal. calcd for $\mathrm{C}_{17} \mathrm{H}_{12} \mathrm{ClF}-$ $\mathrm{N}_{4} \mathrm{O}_{2} \mathrm{~S}: \mathrm{C}, 52.24 ; \mathrm{H}, 3.09 ; \mathrm{N}, 14.34$. Found: $\mathrm{C}, 52.23 ; \mathrm{H}, 3.08 ; \mathrm{N}$, $14.33 \%$.

1-(3-chloro-2-oxo-4-(m-tolyl) azetidin-1-yl)-3-(5-fluorobenzo[d] thiazol-2-yl)urea (A8)

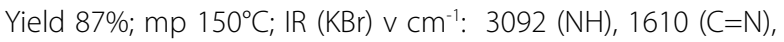
1150 (C-F); ${ }^{1} \mathrm{H}$ NMR (DMSO-d $)$ ) $(\mathrm{ppm}): 2.18\left(\mathrm{~s}, 1 \mathrm{H}, \mathrm{CH}_{3}\right), 11.34$ $(\mathrm{S}, 1 \mathrm{H}, \mathrm{NH}), 8.72(\mathrm{~s}, 1 \mathrm{H}, \mathrm{CONH})$, Anal. calcd for $\mathrm{C}_{18} \mathrm{H}_{14} \mathrm{ClFN}_{4} \mathrm{O}_{2} \mathrm{~S}$ : C, 53.40; H, 3.49; N, 13.84. Found: C, 53.39; H, 3.38; N, 13.83\%.

1-(3-chloro-2-oxo-4-(o-tolyl) azetidin-1-yl)-3-(5-fluorobenzo[d] thiazol-2-yl)urea (A9)

Yield 88\%; $\mathrm{mp} 195^{\circ} \mathrm{C} ; \mathrm{IR}(\mathrm{KBr}) \vee \mathrm{cm}^{-1}: 1674(\mathrm{C}=\mathrm{O}), 3094(\mathrm{NH})$, $1604(\mathrm{C}=\mathrm{N}), 1157(\mathrm{C}-\mathrm{F}), 728(\mathrm{C}-\mathrm{S}), 1685(\mathrm{C}=\mathrm{C}) ;{ }^{1} \mathrm{HNMR}$ (DMSO-d6 ) $\delta(\mathrm{ppm}): 2.16\left(\mathrm{~s}, 1 \mathrm{H}, \mathrm{CH}_{3}\right), 11.34(\mathrm{~s}, 1 \mathrm{H}, \mathrm{NH}), 3.57(\mathrm{~s}, 1 \mathrm{H}$, azetidin $\left.\left.\mathrm{C}_{4}-\mathrm{H}\right),\right), 5.64(\mathrm{~s}, 1 \mathrm{H}, \mathrm{CH}-\mathrm{Cl}), 8.77(\mathrm{~s}, 1 \mathrm{H}, \mathrm{CONH})$. Anal. calcd for $\mathrm{C}_{18} \mathrm{H}_{14} \mathrm{CIFN}_{4} \mathrm{O}_{2} \mathrm{~S}$ : C, 53.40; $\mathrm{H}, 3.49 ; \mathrm{N}, 13.84$. Found: $\mathrm{C}, 53.38 ; \mathrm{H}$, $3.38 ; \mathrm{N}, 13.82 \%$.

1-(3-chloro-2-oxo-4-(o-methoxy) azetidin-1-yl)-3-(5-fluorobenzo[d] thiazol-2-yl)urea (A10)

Yield 85\%; $\mathrm{mp} 180^{\circ} \mathrm{C}$; IR(KBr) $\vee \mathrm{cm}^{-1}: 1674(\mathrm{C}=\mathrm{O}), 3093(\mathrm{NH})$, 1600 (C=N), 1150 (C-F), 725 (C-S), 1650 (C=C); ${ }^{1} \mathrm{HNMR}$ (DMSOd6 ) $\delta$ (ppm): $3.89\left(\mathrm{~s}, 3 \mathrm{H},-\mathrm{OCH}_{3}\right), 9.44(\mathrm{~s}, 1 \mathrm{H}, \mathrm{NH}), 4.25(\mathrm{~s}, 1 \mathrm{H}$, azetidin $\left.\mathrm{C}_{3}-\mathrm{H}\right), 4.15(\mathrm{~s}, 1 \mathrm{H}, \mathrm{CH}-\mathrm{Cl}), 8.45(\mathrm{~s}, 1 \mathrm{H}, \mathrm{CONH})$. Anal. calcd for $\mathrm{C}_{18} \mathrm{H}_{14} \mathrm{CIFN}_{4} \mathrm{O}_{3} \mathrm{~S}: \mathrm{C}, 51.37 ; \mathrm{H}, 3.35 ; \mathrm{N}, 13.31$. Found: C, 51.36; $\mathrm{H}$, $3.34 ; \mathrm{N}, 13.30 \%$.

\section{In vitro evaluation of antimycobacterial activity}

\section{Determination of minimal inhibition concentrations}

The test compounds were subjected to screening by the Lowenstein-Jensen method using Mycobacterium tuberculosis H37Rv strain (MTCC 200) (L.J. method) (Patel et al. 2011). All the synthesized compounds were screened for antitubercular activity at Micropharm Laboratory, Gandhinagar.

\section{Preparation of medium}

Eggs were broken aseptically to obtain $500 \mathrm{~mL}$ of egg solution. The solution was filtered through a sterile muslin cloth into a sterile conical flask containing glass beads. A sterilized mineral salt solution (consisting of $1.2 \mathrm{~g}$ potassium phosphate, $0.12 \mathrm{~g}$ magnesium sulfate, $0.3 \mathrm{~g}$ magnesium citrate, $1.8 \mathrm{~g} / \mathrm{L}$ asparagine, $6 \mathrm{~mL}$ glycerol, and $300 \mathrm{~mL}$ distilled water) and $4 \mathrm{~mL}$ sterilized malachite green solution $16 \mathrm{~mL}$ (2.0\%) were added to 


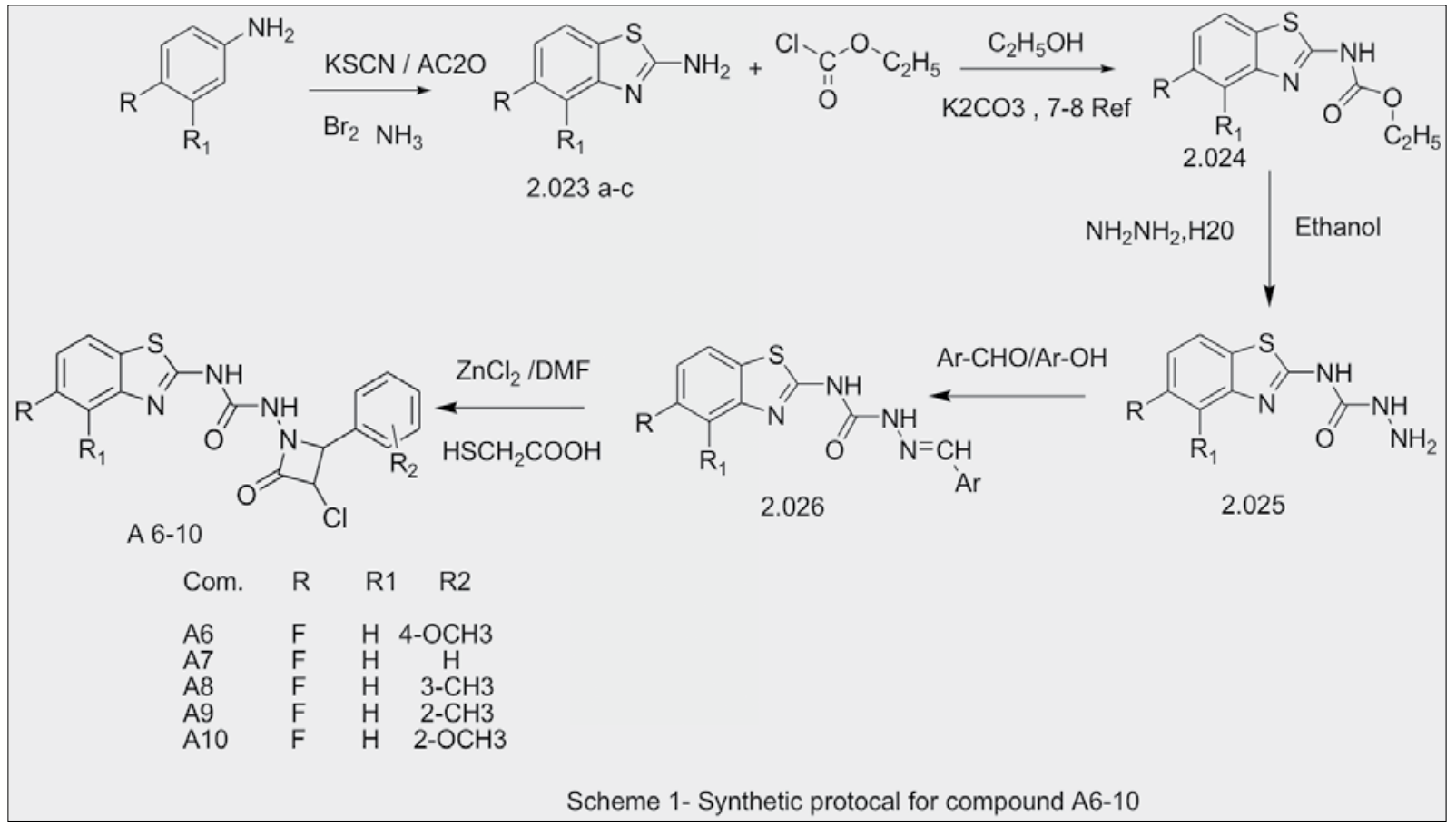

Figure 1. Synthetic protocol for compound A6-10

\section{Table 1. The in vitro screening data indicating the antitubercular activity}

\begin{tabular}{|c|c|c|c|c|}
\hline \multirow[b]{2}{*}{ Com no } & \multirow[b]{2}{*}{$\begin{array}{l}\text { Chemical } \\
\text { structure }\end{array}$} & \multicolumn{2}{|c|}{ Concentration of compound } & \multirow[b]{2}{*}{ MIC } \\
\hline & & $\begin{array}{c}25 \mu \mathrm{g} / \mathrm{mL} \\
\text { (\% Growth) }\end{array}$ & $\begin{array}{c}50 \mu \mathrm{g} / \mathrm{mL} \\
\text { (\%Growth) }\end{array}$ & \\
\hline 06 & & $0 \%$ & $0 \%$ & $25 \mu \mathrm{g} / \mathrm{mL}$ \\
\hline 07 & & $100 \%$ & $100 \%$ & $50 \mu \mathrm{g} / \mathrm{mL}$ \\
\hline 08 & & $100 \%$ & $0 \%$ & $50 \mu \mathrm{g} / \mathrm{mL}$ \\
\hline 09 & & $100 \%$ & $100 \%$ & $\rightarrow 50 \mu \mathrm{g} / \mathrm{mL}$ \\
\hline 10 & & $100 \%$ & $0 \%$ & $50 \mu \mathrm{g} / \mathrm{mL}$ \\
\hline 09 & Isoniazid & 0 & 0 & $25 \mu \mathrm{g} / \mathrm{mL}$ \\
\hline 10 & Rifampicin & 0 & 0 & $25 \mu \mathrm{g} / \mathrm{mL}$ \\
\hline
\end{tabular}

the $500 \mathrm{~mL}$ egg solution. The contents were commixed well to obtain a uniform medium.

The compounds (3 mg) were dissolved in $1.5 \mathrm{~mL} \mathrm{DMSO}$ and diluted using DMSO to prepare $2000 \mu \mathrm{g} / \mathrm{mL}$ of stock solutions. Two concentrations, 50 and $25 \mu \mathrm{g} / \mathrm{mL}$, were acclimated to evaluate the antitubercular activity. A $0.5-\mathrm{mL}$ aliquot of each concentration was transferred into different McCartney bottles. Then, $5 \mathrm{~mL}$ of L.J. medium was added and commixed well. The mixture was homogenized in a vortex mixer for $1 \mathrm{~min}$, and if required, the opacity was adjusted by adding sterile distilled water. Screw-capped tubes containing $5 \mathrm{~mL}$ medium were inspissated at $85^{\circ} \mathrm{C}$ for $40-45 \mathrm{~min}$. This inspissation process was repeated three times.

Isoniazid and rifampicin (3 mg) were chosen as the standard drugs for the comparison of antitubercular activity. The drug was dissolved in DMSO and diluted and tested as described above. The bottles were incubated at $75^{\circ} \mathrm{C}-80^{\circ} \mathrm{C}$ for 3 days for solidification and sterilization.

\section{Procedure for inoculation}

For culture inoculation, $1 \mu \mathrm{g} / \mathrm{mL}$ of the standard suspension was diluted and $0.2 \mathrm{~mL}$ of the inoculums was added to each tube. After inoculation, the tubes were incubated at $37^{\circ} \mathrm{C}$ in a slanted position with the screw cap scarcely loosened to allow evaporation of the inoculum. After 24-48 h, the screw caps were tightened and the tubes were further incubated. Results were read on the $28^{\text {th }}$ and $56^{\text {th }}$ day after inoculation. The reading of the results is predicated by counting the magnification on the different slants and the calculation of the proportion of bacilli was carried out by comparing counts on drug-free (control) and drug-containing L-J media.

\section{RESULTS AND DISCUSSION}

\section{Chemistry}

The reaction sequence for the titled compound is outlined in Figure 1. The reaction between 2-aminobenzothiazole and anhydrous $\mathrm{K}_{2} \mathrm{CO}_{3^{\prime}}$ ethyl chloroformate, and ethanol provided ethyl (1,3-benzothiazol-2-yl) carbamate through the reaction with hydrazine hydrate and ethanol to produce N-(5-fluorobenzothiazol-2-yl) hydrazine carboxamide. N-(5-fluorobenzothiazol-2-yl) hydrazine carboxamide was again treated with different aromatic aldehydes to yield the Schiff base. The obtained 
Schiff base was treated with chloroacetyl chloride and triethyl amine in the presence of DMF to obtain the corresponding derivatives (A6-10).

\section{Antitubercular activity}

The ability of the compounds A6-10 to inhibit the growth of M. tuberculosis was determined using an in vitro assay. The results are summarized in Table 1. Each compound was dissolved in DMSO. The in vitro screening data (Table 1) indicated that all analogs exhibited significant antitubercular activity compared to that of the reference drugs isoniazid and rifampicin. A comparison of the antitubercular activity of the compounds A6-10 with that of the compounds containing the $\mathrm{OCH}_{3}$ group at the $\mathrm{C}-4$ position of the phenyl ring and the $\mathrm{CH}_{3}$ group at the $\mathrm{C}-2$ position of the phenyl ring showed maximum and low activity. These results indicate that compound A6 is more active than the other compounds, perhaps because of their low partition coefficient and, consequently, the low penetration ability through the mycobacterium cell wall.

\section{CONCLUSION}

Ten azetidinone derivatives were synthesized and characterized by TLC, IR, and ' $H$ NMR. The purity of the products was confirmed by elemental analysis. The in vitro screening data revealed that all the designed and synthesized compounds (A6-10) exhibited the ability to inhibit the growth of M. tuberculosis in terms of MIC.

\section{REFERENCES}

- $\quad$ Patel VR, Patel CN, Sen DJ (2011). Synthesis and Biological evaluation of some 5-[(substituted)-Phenyl]-3-(4-Chlorophenyl)-4,5Dihydro-1H-Pyrazole-1 Carbathiomide Derivatives. Internationale Pharmaceutica Sciencia 1(1): 133-136.

- Sarkar S, Pasha TY, Shivakumar B, Reddy VM (2008). Synthesis and Evaluation of Antibacterial and Antiinflammatory Activity of 7-Alkyl/Aryl amino-6-fluoro-2- phenyl Carboxamido-1,3-benzothiazoles. Asian J Chem 20(4): 3227-3230.

- Sarkar S, Pasha TY, Shivakumar B, Chimkode R (2008). Synthesis of benzothiazole derivatives and study of their anti-fungal activities. Oriantal J Chem 24(2): 705-708.

- $\quad$ Sarkar S, Pasha TY, Shivakumar B, Chimkode R (2008). Synthesis of new 7-alkyl /aryl amino -6-fluro 2 substituated phenyl carboxamido (1,3) benzothiazoles as anthelmintic agents. Indian J Heterocycl. Chem 24(7): 383-388.

- Sarkar S (2011). Synthesis and Pharmacological evaluation of New 7 alkyl/ aryl amino-6-fluro 2- (3 nitro phenyl) Carboxamido (1,3) benzothiazole as anthelmintic agents. J Pharm Res 1(12): 4599.

- Sarkar S, Dwivedi J, Chauhan R (2013). Synthesis and biological activity of novel azetidinone and thiazolidinone starting from benzothiazole. Ind J Heterocyclic Chem 23: 75-80.

- Sarkar S, Dwivedi J, Chauhan R (2013). Synthesis of 1-[2 (substituted phenyl)-4-oxothiazolidin-3-yl]-3-(6-fluro-7-chloro-1,3benzothiazol-2-yl)-ureas as anthelmintic agent. J Pharm Res 5(7) 439-442. [CrossRef]

- Sarkar S (2017). Synthesis and antimicrobial activity of Some azetidinone derivatives Containing Substituted Benzothiazole. Indian J Heterocycl. Chem 69(1): 46-50. 